\title{
The occurrence of abnormal serum proteins in patients with epithelial neoplasms
}

\author{
WENDY J. LYNCH AND R. A. JOSKE \\ From the Department of Biochemistry, Royal Perth Hospital, and Department of Medicine, \\ University of Western Australia, Perth, Western Australia
}

SYNOPSIS In a series of 99 patients with paraproteinaemia, nine had carcinoma without myeloma. A review of the literature suggests that this may be a significant association, and its theoretical and clinical significance is discussed.

Abnormal proteins have been known for some time to occur in sera from patients with multiple myeloma and other neoplasms of reticulo-endothelial cells, as well as macroglobulinaemia and cryoglobulinaemia (Adams, Alling, and Lawrence, 1949; Fudenberg and Kunkel, 1957; Azar, Hill, and Osserman, 1957; Putnam, 1960; Waldenström, 1961; Osserman and Takatsuki, 1963; Sunderman, 1964; Franklin and Lowenstein, 1964). Similar proteins may also occur in sera from patients with no apparent causal disease (Waldenström, 1952; Laurell, Laurell, and Waldenström, 1957; Osserman, 1958; Owen, Pitney, and O'Dea, 1959; Waldenström, 1961; Hammack and Frommeyer, 1962).

Most of these papers, whether discussing multiple myeloma or paraproteinaemia, mention the occasional occurrence of patients with paraproteinaemia and epithelial rather than reticulo-endothelial neoplasms. Adams et al. (1949) reviewed 61 patients with myeloma, and noted a further two with paraproteins and carcinoma. One of these had a carcinoma of the stomach; in the other the primary site was unknown although widespread bony metastases were present. Similarly, Owen et al. (1959) found one of nine patients with paraproteinaemia but without myeloma to have a thyroid carcinoma with metastases in ribs. Eight of the 24 patients with 'premyeloma' reported by Osserman (1958) had carcinoma at different primary sites. Hammack and Frommeyer (1962) studied 37 patients with paraproteinaemia not associated with myeloma, and found five with epithelial neoplasms, the primary sites being lung two, rectum two, and prostate. These paraproteins were of IgG type. (Here and subsequently nomenclature has been altered to conform with that of the World Health Organization, 1964.) Received for publication 21 April 1966.
Viallet, Benhamou, Berthelot, Hartmann, and Fauvert (1962) reported in detail a patient with a hepatoma secondary to portal cirrhosis and an abnormal IgM globulin. They found three other reports in the literature of liver carcinoma associated with paraproteinaemia. One of these was described by Creyssel, Fine, and Morel (1959), who also reported a patient with carcinoma of the kidney and paraproteinaemia.

Other papers have dealt with the problem more specifically. Wuhrmann (1947) emphasized an association between macroglobulinaemia and cancer, a finding confirmed by Hammack and Frommeyer (1962). Surveys of large numbers of patients whose sera contained paraproteins have been reported by Waldenström (1961) and Osserman and Takatsuki (1963). The former discussed 269 patients whose sera contained M-type $\gamma$-globulins. In 12 the clinical diagnosis was carcinoma. Two had carcinoma of the external bile ducts, four carcinoma of the prostate (two with extensive skeletal metastases), two carcinoma of the colon, and four carcinoma of the female genital tract. Other patients in the series had either carcinoma treated before, or developing subsequent to, the recognition of paraproteinaemia. The types of paraprotein in the patients with carcinoma varied and included IgG, IgA, and IgM globulins.

Osserman and Takatsuki (1963) reported a similar investigation of 400 cases, and found 31 with " "monoclonal gammopathy" of unknown aetiology with associated neoplasm'. These included carcinomata of the rectosigmoid (nine cases), prostate (five), breast (four), oropharynx (four), bile ducts (two), and stomach, jejunum, pancreas, uterus, and bladder (one each). Twenty-eight had IgG globulins, two had IgM, and one an IgA globulin. Sites of metastases were not discussed. 
TABLE I

SUMMARY OF CLINICAL AND LABORATORY FINDINGS IN NINE PATIENTS WITH CARCINOMA AND PARAPROTEINAEMIA

\begin{tabular}{|c|c|c|c|c|c|c|c|c|c|}
\hline $\begin{array}{l}\text { Case } \\
\text { No. }\end{array}$ & $\begin{array}{l}\text { Age } \\
\text { (yr.) }\end{array}$ & Sex & Type of Carcinoma & $\begin{array}{l}\text { Meta- } \\
\text { stases }\end{array}$ & Other Clinical Findings & $\begin{array}{l}\mathrm{Hb} \\
(\mathrm{g} . \%)\end{array}$ & $\begin{array}{l}\text { W.B.C.s } \\
\left(10^{3} / \text { c. } \mathrm{mm} .\right)\end{array}$ & $\begin{array}{l}\text { Lymphocytes } \\
\% \text { of W.B.C.s }\end{array}$ & $\begin{array}{l}\text { Absolute } \\
\text { s Lymphocyte } \\
\text { Count }\end{array}$ \\
\hline 1 & 52 & $\mathbf{F}$ & Basal cell of skin & No & Psychosis & $14 \cdot 6$ & $8 \cdot 0$ & 13 & 1,040 \\
\hline 2 & 68 & $\mathbf{F}$ & Simplex of breast & $?$ & Diabetes mellitus & $10 \cdot 4$ & $11 \cdot 6$ & 40 & 4,640 \\
\hline 3 & 80 & $\mathbf{F}$ & $\begin{array}{l}\text { Adenocarcinoma of } \\
\text { stomach }\end{array}$ & Yes & - & $7 \cdot 2$ & $6 \cdot 7$ & 15 & 1,005 \\
\hline 4 & 85 & $\mathbf{M}$ & $\begin{array}{l}\text { Adenocarcinoma of } \\
\text { stomach }\end{array}$ & Yes & - & $6 \cdot 5$ & $10 \cdot 0$ & 34 & 3,400 \\
\hline 5 & 40 & $\mathbf{F}$ & $\begin{array}{l}\text { Undifferentiated } \\
\text { spheroidal cell } \\
\text { ? alimentary origin }\end{array}$ & Yes & - & $13 \cdot 3$ & $8 \cdot 0$ & 30 & 2,400 \\
\hline 6 & 68 & $\mathbf{M}$ & $\begin{array}{l}\text { Adenocarcinoma of } \\
\text { stomach }\end{array}$ & Yes & - & $11 \cdot 3$ & $6 \cdot 0$ & 21 & 1,260 \\
\hline 7 & 69 & $\mathbf{M}$ & Basal cell of skin & No & $\begin{array}{l}\text { Pulmonary insufficiency, } \\
\text { cholelithiasis }\end{array}$ & $17 \cdot 3$ & $12 \cdot 4$ & 4 & 496 \\
\hline 8 & 76 & $\mathbf{M}$ & $\begin{array}{l}\text { Adenocarcinoma of } \\
\text { kidney }\end{array}$ & No & $\begin{array}{l}\text { Hypertension, cerebral } \\
\text { haemorrhage }\end{array}$ & $14 \cdot 3$ & $4 \cdot 8$ & 22 & 1,056 \\
\hline
\end{tabular}

A different approach to the problem was made by Weitzel (1958), who studied in a necropsy series the coexistence of carcinoma and malignant disorders of plasma cells, although without reference to paraproteinaemia. He found carcinoma in 11 of 57 such cases. The primary sites included prostate (three cases), stomach, small gut, and large gut (two each), and tonsil and scrotum (one each). Metastases were present in only three cases. Weitzel produced evidence that this association was not soley due to chance.

The literature thus provides evidence that from $3 \%$ to $7 \%$ of patients with paraproteinaemia will have an epithelial neoplasm, and that this may be a significant association. The primary sites vary greatly, although the high frequence of prostatic, intestinal, and hepatic tumours, and the low frequency of primary carcinoma of the lung are worthy of further investigation. The presence or absence of metastases in bone or liver appears to be without significance. Because of the possible importance of the association of paraproteinaemia and epithelial neoplasm, the present paper reports a further nine such cases, occurring in a series of 99 patients with paraproteinaemia.

\section{LABORATORY METHODS}

Electrophoresis of serum proteins was done on cellulose acetate using a barbitone buffer by the method of Brackenridge (1960). Immunoelectrophoresis was by a modification of the method of Scheidegger (1955) microtechnique using $1 \%$ agar in barbitone buffer at $p \mathrm{H} \mathrm{8.4}$ and commercial preparations of antisera.

\section{RESULTS}

In the period 1960-65 inclusive, paraproteins were found in sera from 99 patients admitted to the Royal Perth Hospital or referred for investigation. Diagnoses reached in these cases are shown below. There were nine patients with epithelial neoplasm; brief details of these patients are included in Table I.

DIAGNOSES REACHED IN PATIENTS WITH PARAPROTEINAEMIA AT THE ROYAL PERTH HOSPITAL 1960-1965

Diagnostic Group

No. of Cases

Myelomatosis

Macroglobulinaemia of Waldenstrom

Essential cryoglobulinaemia

Other reticulo-endothelial neoplasms

Epithelial neoplasms

No diagnosis or incomplete investigation

Total

43
9
1
4
9
33
99

The nine patients included five females and four males, with an age range from 40 to 85 years, and a mean of 66 years. The sites of origin of carcinoma varied; alimentary tract neoplasms predominated and no patient had a carcinoma of the lung. Presence and sites of metastasis did not appear significant. The haematological findings were also not significant. Anaemia, when present, was of iron-deficiency type. Lymphocyte counts varied from a lymphopaenia to a considerable lymphocytosis. No plasmacytosis was found in the bone marrow in the five cases where it was examined. None of the patients had Bence-Jones proteinuria.

The appearance, size, and position of the abnormal band on the cellulose acetate strip varied, and it was not distinguishable from paraprotein bands found in patients with myeloma or other conditions. Immunoelectrophoretic studies in five of the nine cases showed the paraprotein to be IgG in all five. Levels of $\alpha 2$-globulins were generally raised as is not infrequent in patients with carcinoma. 
TABLE I (Continued)

SUMMARY OF CLINICAL AND LABORATORY FINDINGS IN NINE PATIENTS WITH CARCINOMA AND PARAPROTEINAEMIA

\begin{tabular}{|c|c|c|c|c|c|c|c|}
\hline \multirow{2}{*}{$\begin{array}{l}\text { Bone-marrow } \\
\text { Examination }\end{array}$} & \multicolumn{6}{|c|}{ Serum Proteins $(\mathrm{g} . / 100 \mathrm{ml})}$. & \multirow{2}{*}{ Comment } \\
\hline & Albumin & a 1-globulin & a 2-globulin & $\beta$-globulin & $\gamma$-globulin & Paraprotein & \\
\hline $\begin{array}{l}\text { N.A.D. } \\
\text { - }\end{array}$ & $\begin{array}{l}3 \cdot 70 \\
2 \cdot 95 \\
2 \cdot 68\end{array}$ & $\begin{array}{l}0.40 \\
0 \cdot 26 \\
0.39\end{array}$ & $\begin{array}{l}0.85 \\
1.02 \\
0 \cdot 79\end{array}$ & $\begin{array}{l}0.96 \\
1.05 \\
0.82\end{array}$ & $\begin{array}{l}1 \cdot 92^{1} \\
1 \cdot 27^{1} \\
1 \cdot 12^{1}\end{array}$ & $\begin{array}{l}\text { Band slow } \gamma \mathbf{I g G} \\
\overline{\text { Band mid } \gamma \mathrm{IgG}}\end{array}$ & $\begin{array}{l}\text { Wassermann reaction positive } \\
\text { Iron-deficiency anaemia }\end{array}$ \\
\hline Iron deficiency & 1.68 & 0.41 & 0.91 & 0.89 & $1 \cdot 74^{1}$ & Band slow $\gamma$ IgG & \\
\hline - & $3 \cdot 56$ & 0.39 & 0.96 & 0.83 & $0.80^{1}$ & Band slow $\gamma$ & No necropsy \\
\hline N.A.D. & 3.44 & $0 \cdot 44$ & 1.03 & 1.02 & $1 \cdot 31^{1}$ & Band mid $\gamma \mathrm{IgG}$ & \\
\hline N.A.D. & 2.44 & 0.56 & $1 \cdot 17$ & 0.80 & $1 \cdot 81^{1}$ & - & Paraprotein preceded neoplasm \\
\hline N.A.D. & $3 \cdot 27$ & 0.41 & 0.81 & 0.70 & $1 \cdot 61^{1}$ & Band slow $\gamma$ IgG & No necropsy \\
\hline - & 1.95 & 0.44 & 0.73 & 0.71 & $0.63^{1}$ & Band slow $\gamma$ & Iron-deficiency anaemia \\
\hline
\end{tabular}

${ }^{1}$ Includes abnormal band.

\section{DISCUSSION}

This series of cases agrees with others reported in the literature in all major respects. There is an associated carcinoma in over $5 \%$ of patients with paraproteinaemia and these patients rarely show evidence of myelomatosis. The sites of origin of the carcinomata vary, but in all series there is a high proportion of alimentary carcinoma and a low proportion of bronchogenic carcinoma. No explanation of this is known. Again, the presence of bony or hepatic metastases is not related to paraproteinaemia.

There is no proof that this association is significant, but the similarity of the findings of different investigations suggests that it may be. Weitzel (1958) provided evidence of a significant association between carcinoma and plasma cell neoplasm, but did not investigate paraproteinaemia. If eventually proven, however, the association raises questions of theoretical and practical importance.

In myelomatosis, paraproteinaemia is thought to be due to the production of abnormal protein by a neoplastic clone of plasma cells arising by somatic mutation. When paraproteinaemia occurs without myeloma, as in apparently healthy persons, this type of explanation is still valid, the mutation affecting antibody protein production by the clone, but not (initially at least) allowing unrestricted cell division. Where, as in the present cases, the neoplastic change affects epithelial rather than reticulo-endothelial cells, a different explanation must be sought.

It is improbable that the carcinoma itself produces paraprotein, for excision of the carcinoma does not necessarily eliminate paraproteinaemia (Waldenström, 1961 ; present cases), though this may occasionally occur (Bohrod, 1957). It may be, therefore, that the paraproteinaemia is the result of disordered antibody production to the carcinoma or the altered tissue field which gives rise to the carcinoma. There is an extensive literature showing the presence of antibodies to carcinoma. In addition increased numbers of plasma cells have been reported in the bone marrow of occasional patients with carcinoma but without paraproteinaemia (Klein and Block, 1953; Aherne, 1958).

At the clinical level, there appears an obligation in the physician to search for occult carcinoma in a patient with paraproteinaemia but without myelomatosis.

\section{REFERENCES}

Adams, W. S., Alling, E. L., and Lawrence, J. S. (1949). Amer. J. Med., 6, 141.

Aherne, W. A. (1958). J. clin. Path., 11, 326.

Azar, H. A., Hill, W. T., and Osserman, E. F. (1957). Amer. J. Med., 23, 239.

Bohrod, M. G. (1957). J. Amer. med. Ass., 164, 18.

Brackenridge, C. J. (1960). Analyt. Chem., 32, 1357.

Creyssel, R., Fine, J. M., and Morel, P. (1959). Rev. Hémat., 14, 238.

Franklin, E. C., and Lowenstein, J. (1964). Seminars Hemat., 1, 144.

Fudenberg, H. H., and Kunkel, H. G. (1957). J. exp. Med., 106, 689.

Hammack, W. J., and Frommeyer, W. B., Jr. (1962). Clin. Res., 10, 200.

Klein, H., and Block, M. (1953). Blood, 8, 1034.

Laurell, C. B., Laurell, H., and Waldenström, J. (1957). Amer. J. Med., 22, 24.

Osserman, E. F. (1958). Radiology, 71, 157.

-, and Takatsuki, K. (1963). Medicine (Baltimore), 42, 357.

Owen, J. A., Pitney, W. R., and O'Dea, J. F. (1959). J. clin. Path., 12, 344.

Putnam, F. W. (1960). Abnormal serum globulins. In The Plasma Proteins, edited by F. W. Putnam, vol. 2, p. 345. Academic Press, New York and London.

Scheidegger, J. J. (1955). Int. Arch. Allergy, 7, 103.

Sunderman, F. W., Jr. (1964). Amer. J. clin. Path., 42, 1.

Viallet, A., Benhamou, J. P., Berthelot, P., Hartmann, L., and Fauvert, R. (1962). Gastroenterology, 43, 88.

Waldenström, J. (1952). Advanc. intern. Med., 5, 398.

(1961). Acta med. scand., suppl. 367, 110.

Weitzel, R. A. (1958). Cancer (Philad.), 11, 546.

World Health Organization (1964). Bull. Wld Hlth Org., 30, 447.

Wuhrmann, F. (1947). Schweiz. Z. Path., 10 (suppl.), 202. Cited by Laurell et al., loc. cit. 